\author{
Akunnaya P. OPOKO \\ Eziyi O. IBEM \\ Ekundayo A. ADEYEMI
}

\title{
Stanovanjske aspiracije v neformalnem urbanem naselju: študija primera
}

Stanovanjske aspiracije so pomemben vidik analize stanovanjskega trga, vendar obstaja le malo empiričnih raziskav stanovanjskih aspiracij prebivalcev neformalnih naselij v državah v razvoju. Zato avtorji v tej raziskavi preučujejo stanovanjske aspiracije prebivalcev neformalnega naselja Ayobo v Lagosu v Nigeriji. Izvedli so presečno raziskavo 1.151 gospodinjstev v naselju, pri čemer so kot orodje za zbiranje podatkov uporabili strukturirani vprašalnik. Podatke so preučili z opisno statistično in kategorično regresijsko analizo. Rezultati so pokazali, da ima večina anketirancev nizke dohodke in živi v najemniških stanovanjih ali sobah v skupnih hišah (ang. rooming houses). Približno $73 \%$ anketirancev se namerava preseliti drugam; od teh se jih $56 \%$ namerava preseliti v stanovanja $\mathrm{z}$ lastno kuhinjo in kopalnico. Razlogi za selitev so slabo stanje trenutnih bivališč, spremembe lastništva in veliko- sti gospodinjstva ter želja po uporabi lastne kuhinje in kopalnice. Poleg teh razlogov so se način odstranjevanja odpadkov, skupna raba kuhinje in kopalnice, zaposlenost, starost in zakonski stan izkazali za dejavnike, ki so najbolje napovedali stanovanjske aspiracije anketirancev. To pomeni, da bi morali gradbeni investitorji za to, da uresničijo preference in aspiracije prebivalcev nigerijskih neformalnih naselij, nameniti ustrezno pozornost zakonskemu stanu, starosti, zaposlitvi in lastništvu stanovalcev ter dati poudarek gradnji cenovno dostopnih enodružinskih hiš in stanovanjskih blokov, kot tudi strategijam izboljšanja dostopa do osnovne infrastrukture in storitev.

Ključne besede: neformalna naselja, stanovanjske aspiracije, stanovanjske preference, namera o preselitvi, Lagos 


\section{Uvod}

Stanovanje ima pomembno kulturno, družbenoekonomsko, okoljsko in politično vlogo v življenju posameznikov, gospodinjstev in narodov. Akunnaya P. Opoko idr. (2014) ugotavljajo, da imajo Nigerijci v zadnjem času izjemno velike aspiracije po lastniškem stanovanju ali hiši. Uprave v veliko velemestih, kot je Lagos, zaradi omejenih virov in $\mathrm{v}$ nekaterih primerih kratkovidnosti ne morejo zadovoljiti stanovanjskih aspiracij večine prebivalcev, še zlasti ne tistih, ki živijo v neformalnih naseljih (UN-HABITAT, 2006). Zato morajo gospodinjstva z nizkimi dohodki sama poskrbeti zase, pri čemer se pogosto usmerijo na neformalni stanovanjski trg, ki ga Ashley Gunter (2014) opisuje kot klasični neoliberalni trg, na katerem je stanovanjska ponudba slaba in povpraševanje stalno visoko, ljudi pa skrbijo kakovost, cena in varnost lastništva. Somik V. Lall idr. (2005) navajajo, da večina teh gospodinjstev le začasno živi v neformalnih naseljih, saj si številna želijo v prihodnosti zagotoviti boljše stanovanjske razmere.

Najnovejši ukrepi, ki jih je nigerijska vlada sprejela za zadovoljevanje stanovanjskih aspiracij svojih prebivalcev, vključujejo reorganizacijo zveznega stanovanjskega urada, ki naj bi tako zagotovil več stanovanj, ter ustanovitev nigerijske družbe za refinanciranje hipotek, ki naj bi Nigerijcem povečala dostop do hipotek (Kolawole, 2015) in sodelovala pri javno-zasebnih partnerstvih na stanovanjskem področju (Ibem, 2011). Žal se je za večino stanovanj, zgrajenih na podlagi strategij zasebnega sektorja, izkazalo, da so za revne predraga (Ibem, 2011) in da se ne skladajo z njihovimi aspiracijami (Jiboye, 2009). To kaže na očitno neskladje med tem, kar ljudje želijo, in tem, kar je na voljo.

Pregled literature kaže, da je aspiracija pojem, $s$ katerim se ukvarjajo najrazličnejše stroke. Stanovanjske aspiracije pa so novejša raziskovalna tema (Edwards, 2005), pri čemer se večina raziskav osredotoča na prebivalce razvitih gospodarstev (Croucher, 2008, in Steele, 2010). Zaradi majhnega števila raziskav stanovanjskih aspiracij v manj razvitih državah, vključno z Nigerijo, je razumevanje stanovanjskih aspiracij mestnih prebivalcev v državah v razvoju nezadostno. Poleg Juliusa O. Gbakejija in Ojeifa O. Magnusa (2007), ki sta preučevala preference glede stanovanjskih sosesk v nigerijskem mestu Warri, se je več nigerijskih raziskav (Jiboye, 2009, ter Ibem in Aduwo, 2013) osredotočalo na zadovoljstvo $s$ stanovanjskimi razmerami, kar je merilo za stanovanjske aspiracije in preference. To potrjuje, da bi bilo treba izvesti več raziskav stanovanjskih aspiracij v Nigeriji v okviru reševanja vse večjega stanovanjskega problema v nigerijskih mestih.
V teh okolišcinah smo preučili stanovanjske aspiracije gospodinjstev v neformalnem naselju Ayobo v predmestju Lagosa v Nigeriji. Glavni cilji raziskave so bili preučiti lastnosti stanovanj, stanovanjsko preteklost in aspiracije prebivalcev ter ugotoviti, kateri dejavniki vplivajo na stanovanjske aspiracije prebivalcev Ayoba. To naselje smo izbrali, ker smo želeli dobiti svež vpogled $\mathrm{v}$ stanovanjske aspiracije gospodinjstev z nizkimi dohodki, kar je zelo pomembno pri prizadevanjih za izboljšanje stanovanjskih razmer $\mathrm{v}$ neformalnih naseljih na mestnih območjih držav v razvoju.

Ključna hipoteza članka je, da je ustrezno razumevanje stanovanjskih aspiracij in preferenc bistveno za doseganje učinkovitega urbanega stanovanjskega trga, ki zadovoljuje pričakovanja in aspiracije vseh kategorij gospodinjstev. $S$ to raziskavo želimo prispevati k doseganju živahnega stanovanjskega trga, in sicer s predstavitvijo pomembnih informacij, ki jih investitorji potrebujejo za gradnjo stanovanj, ki ustrezajo preferencam prebivalcev na preučevanem območju in $\mathrm{v}$ drugih neformalnih mestnih naseljih v Nigeriji, kjer neformalna stanovanja ostajajo velik problem za trajnostno rast mest in njihov razvoj.

\section{Pregled literature}

Pregled literature se deli na tri podpoglavja: neformalna stanovanja $\mathrm{v}$ mestih, stanovanjske aspiracije in dosedanje raziskave stanovanjskih aspiracij.

\subsection{Neformalna stanovanja v mestih}

Preden se lotimo pregleda literature o stanovanjskih aspiracijah, moramo na kratko razložiti okoliščine neformalnih stanovanj v mestih. Neformalni sektor se običajno opisuje kot neobdavčen del gospodarstva, ki ga vlada ali uprava pogosto ne nadzoruje. $\mathrm{V}$ državah $\mathrm{v}$ razvoju je $\mathrm{v}$ ta sektor vključeno do $60 \%$ delovno aktivnega prebivalstva (Fapohunda, 2012). Neformalni sektor je glavni vir preživetja družin in skupnosti $\mathrm{v}$ mestih na globalnem jugu, zaradi česa so raziskovalci trdili, da je neformalno gospodarstvo lokalnega značaja, ima omejene povezave $s$ formalnim gospodarstvom in temelji na preživitvenih praksah, ki veljajo za zelo nekonkurenčne (Oldfield, 2014). Sasha Tsenkova (2014) je neformalni stanovanjski sektor opisala kot sektor z nizko stopnjo vladnega nadzora, slabim dostopom do storitev in podstandardnimi bivalnimi pogoji, ki nudi dom revnim skupnostim, beguncem ali novejšim priseljencem v mesta. V prejšnjih raziskavah so avtorji (Morka, 2007, in Gunter, 2014) ugotovili, da sta v državah na globalnem jugu vse večji primanjkljaj stanovanj in nezadosten fond poceni stanovanj na formalnem stanovanjskem trgu, ki ne more zadovoljiti povpraševanja, povzročila širjenje neformalnih naselij in bivališč. Zato je v številnih mestih na globalnem 
jugu stanovanjski trg neformalen (Gunter, 2014) in v veliko primerih so procesi preoblikovanja trga iz neformalnega $\mathrm{v}$ formalnega prek formalizacije lastninskih pravic povzročili samo še več novih neformalnih oblik (Marais idr., 2014). To potrjuje, da ima neformalni stanovanjski podsektor pomembno vlogo pri zagotavljanju stanovanj v večini mest po svetu (Shapurjee in Charlton, 2013). To pomaga pojasniti, zakaj so raziskave stanovanjskih aspiracij prebivalcev neformalnih naselij postale pomembne za raziskovalce stanovanjskega področja in strokovnjake s področja razvoja mest.

\subsection{Stanovanjske aspiracije}

Sue Clegg idr. (2007: 10) opredeljujejo aspiracijo kot »uresničljiv cilj, ki vpliva na vedenje in izbiro «. Večina ljudi zato meni, da so njihove aspiracije dosegljive (glej Clegg idr., 2007). To pa ni vedno res, saj lahko aspiracije vključujejo tako realistične kot absurdne želje. Medtem ko so realistične aspiracije dosegljive, so želje samo hotenja, ki se morda zaradi omejenih virov nikoli ne bodo uresničila. Aspiracija je sestavljena iz kognitivnih, afektivnih in vedenjskih komponent (Baum in Wulff, 2003). Pomeni izbiro v idealnem svetu ter znamenje in motivacijo za prihodnje zaželene izide (DTZ New Zealand, 2005). Daniel Chi Wing Ho idr. (2012) opisujejo aspiracijo kot posameznikov odnos do kraja, stvari ali procesa. Avtorji dalje razlagajo, da posameznikove stanovanjske aspiracije določajo, kako posameznik ukrepa v svojem grajenem okolju v zvezi s sanacijo ali obnovo. Uresničljivost aspiracij je odvisna od številnih dejavnikov, vključno $\mathrm{z}$ razmerji med njimi ter realnostjo in razpoložljivostjo potrebnih sestavin, kot so finančna sredstva, čas in osebne vrednote (na primer prizadevanja, motivacija, požrtvovalnost, zavzetost in vztrajnost; Baum in Wulff, 2003, in Jasen, 2012). Zato običajno velja, da med tem, kar ljudje želijo, in tem, kar lahko dosežejo, obstaja vrzel v aspiracijah. Caroline W. Kabiru idr. (2014) navajajo, da lahko tovrstne neuresničene aspiracije vodijo $\mathrm{v}$ frustracije in kriminal.

$\mathrm{V}$ povezavi s stanovanjskimi potrebami in aspiracijami Andy Steele (2010) ugotavlja, da se potrebe nanašajo na zahteve, aspiracije pa na preference. Aspiracije so odvisne od asociacij, vzornikov in potrošnje tehnologij (Hyll in Schneider, 2012). Scott Baum in Maryann Wulff (2003) sta za razumevanje aspiracij, zlasti v povezavi z lastniškim stanovanjem, uporabila pojma stanovanjska kariera in potek življenja. Prvi se nanaša na posameznikove selitve $\mathrm{v}$ najemniška stanovanja od takrat, ko se odseli iz hiše ali stanovanja svojih staršev, do takrat, ko postane lastnik stanovanja, drugi pa na vse nize življenjskih dogodkov in družbenih vlog, ki jih posameznik doživi in prevzame v svojem življenju (Giele in Elder, 1998). Zaporedje teh družbenih izkušenj, ki se razlikujejo glede na starost, je lahko pri vsakem posamezniku drugačno. Ti pogledi kažejo, da aspiracije niso statične, temveč so dinamične, saj se spremi- njajo skupaj s posameznikovimi življenjskimi okoliščnami in družbenimi vlogami.

Iz zgoraj opisanega je jasno, da lahko stanovanjske aspiracije opišemo kot želje ali ambicije, ki se oblikujejo iz posameznikovih čustev ter ocen pričakovanj in zaznanih potreb, tudi odzivov na lastnosti bližnje in daljne stanovanjske okolice. Z drugimi besedami, stanovanjske aspiracije so vedenjski odziv na posameznikovo stanovanjsko okolje, ki je posledica povezave osebnih občutij in miselnih ocen njegovega stanovanjskega položaja. To pomeni, da so stanovanjske aspiracije tesno povezane $s$ stanovanjskimi preferencami ljudi in lahko vplivajo na to, kakšen odnos imajo ti do svojega stanovanjskega okolja. To bi lahko pomagalo pojasniti, zakaj poskušajo posamezniki in gospodinjstva svoje stanovanjske aspiracije uresničiti tako, da se preselijo (to je z mobilnostjo; Clegg idr., 2007) ali preuredijo svoje obstoječe stanovanjsko okolje (Croucher, 2008).

\subsection{Dosedanje raziskave}

Čeprav se je s stanovanji ukvarjalo že več nigerijskih raziskav, podroben pregled literature razkrije, da je bilo doslej o stanovanjskih aspiracijah v Nigeriji objavljeno zelo malo. Večina raziskav se je osredotočala na kvalitativno in kvantitativno ocenjevanje stanovanjskih programov, pogosto $\mathrm{z}$ vidika uporabnikov. Več raziskav (na primer Jiboye, 2009; Ibem in Aduwo, 2013, ter Aigbavboa in Thwala, 2014) je razkrilo različne ravni zadovoljstva z obstoječimi stanovanji ter veliko neskladje med trenutnimi stanovanjskimi razmerami in aspiracijami ljudi $\mathrm{v}$ Nigeriji in Južnoafriški republiki. Vse so namreč pokazale, da je to, v kolikšni meri so stanovalci zadovoljni s svojim stanovanjem, merilo, ki pokaže ujemanje med njihovimi stanovanjskimi izkušnjami, preferencami in aspiracijami.

Kathy Arthurson idr. (2007) so preučevali stanovanjske izkušnje in preference ljudi z duševnimi motnjami v Avstraliji. Ugotovili so, da je bila njihova prva izbira lastniško stanovanje. Sanna Markkanen (2009) je preučevala stanovanjske potrebe in aspiracije največje (črnske) etnične skupine in drugih manjšinskih skupin v Veliki Britaniji, britansko svetovalno podjetje Outside Consultants (2009) pa je raziskalo stanovanjske potrebe in aspiracije mladih. V Leicestershiru je Steele (2010) preučeval stanovanjske aspiracije starejših ljudi in ugotovil, da želijo živeti v zasebnih stanovanjih z lastno kopalnico in kuhinjo, blizu javnih storitev in infrastrukture, $v$ manjših soseskah, ki niso namenjene samo starejšim. $V$ raziskovalni študiji sta Burmaa Jamiyansuren in Dana-Nicoleta Lascu (2012) preučevali funkcionalne lastnosti stanovanj, ki so jih mongolska gospodinjstva srednjega razreda upoštevala pri nakupu hiše. Simon Pinnegar idr. (2012) so raziskovali dejavnike, ki so vplivali na stanovanjske odločitve in izide generacije baby boom. Tahmina Rahman (2011) je s kvalitativnimi metodami pre- 
učevala, kako se začasna stanovanja, zgrajena v okviru obnove po naravni nesreči, slej ko prej začnejo ujemati z aspiracijami revnih stanovalcev.

Čeprav Raimi A. Asiyanbola (2012) navaja, da je izražanje stanovanjskih aspiracij posameznega gospodinjstva običajno kulturno pogojena zadeva, ki je v domeni moških, obstajajo podobnosti med stanovanjskimi aspiracijami v različnih družbenoekonomskih, kulturnih, demografskih in geografskih kontekstih. $V$ zvezi z lastninskimi pravicami si namreč večina ljudi želi lastniško stanovanje ali hišo (Pinnegar idr., 2012), za kar so se gospodinjstva pripravljena žrtvovati (Sunshine Coast University, 2011). Clegg idr. (2007) so ugotovili, da sta za številne najemnike glavni motivaciji za selitev lokaci$\mathrm{ja} /$ soseska in vrsta nepremičnine. $\mathrm{V}$ zvezi z revnim prebivalstvom je Laura Edwards (2005) ugotovila, da zanj lastniško stanovanje ni poglavitni cilj. Druge raziskave so pokazale, da se kljub padcu števila lastnikov stanovanj v poznih 70. letih 20. stoletja v Avstraliji (Baum in Wulff, 2003) in po letu 1991 na Novi Zelandiji (Morrison, 2005) dejansko število gospodinjstev, ki imajo željo po lastnem domu, še naprej povečuje. $\mathrm{Na}$ podlagi vseživljenjskega pristopa sta Rosangela Merlo in Peter McDonald (2004) ugotovila, da je zaposlitveni status najpomembnejši dejavnik, ki gospodinjstva spodbudi $k$ temu, da uresničijo svoje aspiracije po lastniškem stanovanju oziroma lastnem domu. Njuna ugotovitev se ujema z izsledki Williama Clarka in Suzanne Davies Withers (1999), ki sta ugotovila, da sta rast dohodkov in služba najpomembnejša razloga za prehod k lastniškemu stanovanju. Zaposlitev ni pomembna le zato, ker omogoča redne dohodke, ampak daje tudi možnost za izboljšanje prihodkov in $s$ tem tudi cenovne dostopnosti stanovanj, kar je za večino gospodinjstev ključno za uresničevanje njihovih sanj (Sunshine Coast University, 2011). Drugi dejavniki vključujejo spremembe življenjskega sloga (Baum in Wulff, 2003), starost in dohodek (Outside Consultants, 2009) ter poroko (Baxter in McDonald, 2004).

Lokacija je še eden od dejavnikov, ki odločilno vplivajo na stanovanjske aspiracije. Pregled literature kaže, da želijo ljudje živeti na lokacijah, ki so varne, imajo dostop do javnih storitev in infrastrukture ter so blizu družbenih mrež (Edwards, 2005). Kompromisi, potrebni za doseganje želene lokacije, so pogosto odvisni od lastnosti posameznega gospodinjstva (DTZ New Zealand, 2005). Po podatkih avstralskega statističnega ura$\mathrm{da}$ (ang. Australian Bureau of Statistics, v nadaljevanju: ABS, 2004) imajo gospodinjstva $\mathrm{z}$ majhnimi otroki raje varne lokacije blizu šol, medtem ko je za samske zaposlene pomembnejša bližina delovnega mesta. ABS (1998) navaja, da na izbiro lokacije vplivajo znanost lokacije, privlačnost, možnosti izboljšanja življenjskega sloga, mirnost in bližina privlačnih geografskih prvin. Čeprav so avtorji nekaterih dosedanjih raziskav (Hall, 2008, ter Harries idr., 2008) ugotovili, da družbeno-kulturne in etnične vezi ter znanost pomembno vplivajo na aspiracije po določeni lokaciji, bi jih lahko zlahka zamenjali za močnejše motivacije, kot so »boljše lokacije« (Markkanen, 2009). Po drugi strani želi veliko gospodinjstev v Ljubljani ostati na obstoječi lokaciji (Uršič, 2005). To še zlasti velja za starejše ljudi in lastnike stanovanj (Steele, 2010). Bethan Harries idr. (2008) so ugotovili, da sta tudi družbeno mreženje in občutek pripadnosti skupnosti pomembna dejavnika, ki spodbujata gospodinjstva, da ostanejo na določeni lokaciji. Na podlagi opisanega lahko ugotovimo, da je ob fizičnih in prostorskih lastnostih stanovanj in hiš njihova lokacija v povezavi s storitvami, zaposlitvijo, šolami, družbeno-kulturnimi vezmi in geografskimi prvinami glavni dejavnik, ki vpliva na aspiracije stanovalcev po selitvi na drugo lokacijo.

Različne raziskave (na primer Steele, 2010, in Sunshine Coast University, 2011) so pokazale, da so zagotovljeno lastništvo, láhko premikanje po stanovanju, zadosten prostor za gospodinjska opravila ter zasebnost in varnost soseske najpomembnejši dejavniki, ki vplivajo na prihodnje stanovanjske aspiracije (zlasti starejših) ljudi. Zgodnejša raziskava vpliva počasne obnove in slabšanja bivalne kakovosti na stanovanjsko mobilnost prebivalcev več stanovanjskih sosesk v Ljubljani (Uršičc, 2005) je razkrila, da so bili potreba po večjem prostoru, lastništvo stanovanj in pričakovane spremembe demografskih značilnosti gospodinjstva glavni razlogi za selitev gospodinjstev iz obstoječih stanovanj. Avtor je v raziskavi ugotovil, da lahko izboljšanje bivalne kakovosti in hitrejša prenova stanovanjskih sosesk prispevata k upadu stanovanjske mobilnosti. Ogromno ljudi si poleg tega želi živeti v samostojnih hišah (Curtin University, 2013) in bungalovih, ki jih je lahko vzdrževati (Community Council of Devon, 2011); stanovanja veljajo za prenapolnjena, neizvirna, slabe kakovosti in gosto pozidana, poleg tega naj bi negativno vplivala na kakovost družabnega življenja (Rankin, 1983). Kljub temu je raziskava, ki jo je podjetje Outside Consultants (2009) opravilo med mladimi, pokazala močno preferenco po skupnih najemniških stanovanjih. Drugi dejavniki, razvidni iz pregleda literature, so še vrsta hiše, razporeditev prostorov, cena, velikost in kakovost gradnje (Edwards, 2005, in Outside Consultants, 2009). Potreba po dodatnem prostoru se veča s starostjo (Outside Consultants, 2009) in se zdi ključna za nova ali rastoča gospodinjstva (DTZ New Zealand, 2005), ki potrebujejo dodaten prostor za postelje in otroško igro (Edwards, 2005). To se zdi v nasprotju z aspiracijami mongolskih gospodinjstev srednjega razreda, ki si želijo manjših stanovanj (Jamiyansuren in Lascu, 2012). Pomembni dejavniki za gospodinjstva v Veliki Britaniji in Avstraliji so bili tudi interesni konjički in življenjski slog (Markkanen, 2009, ter Pinnegar idr., 2012). Posebni oblikovalski dejavniki, za katere sta Markkanen (2009) in Steele (2010) ugotovila, da vplivajo na stanovanjske aspiracije, vključujejo estetiko, zadovoljstvo z vidika funkcionalnosti in življenjskega sloga, dostop za invalid- 


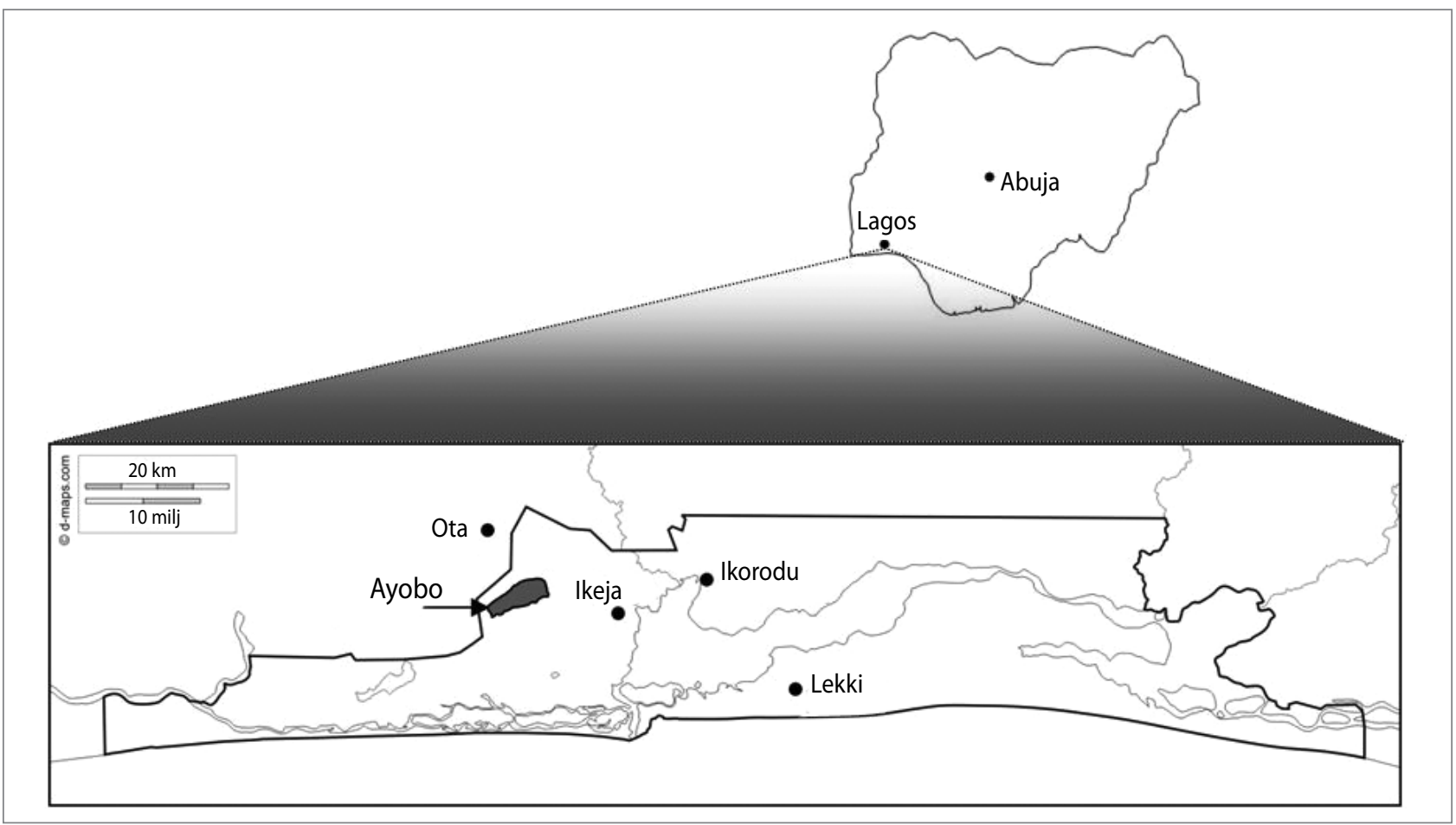

Slika 1: Lokacija Ayoba na zemljevidu (prirejeno po Opoku, 2013)

ske vozičke in ustrezno opremo. Bojan Grum in Darja Kobal Grum (2015) sta preučevala dejavnike, ki jih gospodinjstva upoštevajo pri odločanju za nakup nepremičnine. Ugotovila sta, da so bili med potencialnimi kupci najpomembnejši dejavniki odločanja za nakup nepremičnine nepremičninski in psihološki dejavniki. To pomeni, da značilnosti stanovanj in bližnje okolice ter posameznikova osebnost vplivajo na pričakovanja in aspiracije pri odločanju o vrsti in lokaciji stanovanjske nepremičnine.

Iz predstavljenega pregleda literature je razvidno, da na stanovanjske aspiracije v splošnem vplivajo različni dejavniki, ki vključujejo potrebe ter družbenoekonomske in demografske značilnosti gospodinjstev. Poleg tega je razvidno, da je bila večina dosedanjih raziskav stanovanjskih aspiracij izvedena $\mathrm{v}$ razvitih državah, le malo raziskovalne pozornosti pa je bilo namenjeno državam v razvoju, še zlasti neformalnim mestnim naseljem. Ta raziskava poskuša zapolniti to vrzel.

\section{Raziskovalne metode}

Ayobo je neformalno naselje v predmestju Lagosa v Nigeriji (glej sliko 1). Spada v lokalno upravno območje Alimosho, najgosteje poseljeno lokalno upravno območje zvezne države Lagos, v katerem je leta 2006 živelo okrog 1.319.571 ljudi (nacionalni statistični urad, 2012). Ayobo je trenutno ena redkih osi rasti v Lagosu, kjer močno primanjkuje zemljišč. Kot številna nigerijska neformalna naselja se tudi Ayobo nahaja na mestnem obrobju ter nima zagotovljenih osnovnih storitev in infrastrukture. Zemlja je tam razmeroma poceni v primerjavi z drugimi predeli Lagosa. Z leti se je v Ayobo preselilo veliko prebivalcev Lagosa, ki si niso mogli privoščiti zemlje v drugih delih mesta; to je privedlo do hitre širitve in združitve naselja $\mathrm{z}$ mestom.

Podatki, uporabljeni v članku, so vzeti iz obsežne raziskave strukture lastništva stanovanj med gospodinjstvi v Ayobu, ki je potekala od novembra 2011 do marca 2012. Raziskava je temeljila na anketnem pristopu, ki omogoča zbiranje kvantitativnih in kvalitativnih podatkov o trendih, odnosih ali mnenjih določene populacije glede preučevanih vprašanj na podlagi preučevanja vzorca te populacije (Creswell, 2009). Glavno orodje za zbiranje podatkov je bil strukturirani vprašalnik, pri izbiranju anketirancev pa smo uporabili kombinacijo večstopenjskega stratificiranega in naključnega vzorčenja. Podatki so se zbirali $\mathrm{v}$ treh glavnih fazah: $1 . \mathrm{v}$ času izvajanja ankete smo $\mathrm{z}$ uporabo Googlovega zemljevida najprej določili in šifrirali vse naseljene stavbe v Ayobu, pri čemer smo podatke preverili in posodobili med pregledom na terenu; 2 . v vsaki ulici smo izbrali vsako osmo naseljeno stavbo; 3 . na koncu smo naključno izbrali po eno gospodinjstvo v vsaki stavbi. Glava posameznega izbranega gospodinjstva je pomenila enoto podatkovne analize. Raje smo uporabili Googlov zemljevid kot zemljevide vladnih služb, saj je bil novejši in podrobnejši.

Vprašalnik je sestavil prvi avtor. Vseboval je vprašanja o osebnih značilnostih stanovalcev (na primer spol, starost, dohodek, 
Preglednica 1: Družbenoekonomske značilnosti anketirancev

\begin{tabular}{|c|c|c|}
\hline značilnosti & $n$ & odstotek (\%) \\
\hline \multicolumn{3}{|l|}{ spol } \\
\hline moški & 618 & 53,7 \\
\hline ženska & 533 & 46,3 \\
\hline \multicolumn{3}{|l|}{ starost (v letih) } \\
\hline pod 25 & 107 & 9,3 \\
\hline $25-40$ & 375 & 32,6 \\
\hline $41-50$ & 468 & 40,6 \\
\hline $51-60$ & 156 & 13,5 \\
\hline $61-70$ & 31 & 2,7 \\
\hline nad 70 & 14 & 1,2 \\
\hline \multicolumn{3}{|l|}{ zakonski stan } \\
\hline samski & 169 & 14,7 \\
\hline poročen & 919 & 79,9 \\
\hline vdovec/ločenec/živi ločeno & 63 & 5,5 \\
\hline \multicolumn{3}{|l|}{ stopnja izobrazbe } \\
\hline nobena & 53 & 4,6 \\
\hline osnovna šola & 226 & 19,6 \\
\hline srednja šola & 388 & 33,7 \\
\hline $\begin{array}{l}\text { končan dveletni program na poli- } \\
\text { tehniki (diploma OND) }\end{array}$ & 298 & 25,9 \\
\hline univerzitetna izobrazba & 144 & 12,5 \\
\hline magisterij, doktorat & 42 & 3,7 \\
\hline \multicolumn{3}{|l|}{ zaposlitveni status } \\
\hline upokojen & 257 & 22,4 \\
\hline samozaposlen & 596 & 51,8 \\
\hline zaposlen & 175 & 15,2 \\
\hline nezaposlen & 69 & 6,0 \\
\hline drugo & 54 & 4,7 \\
\hline \multicolumn{3}{|c|}{ mesečni dohodek glave gospodinjstva (NGN)* } \\
\hline brez dohodka & 10 & 0,9 \\
\hline pod 17.000 & 362 & 31,5 \\
\hline $17.000-40.000$ & 417 & 36,2 \\
\hline $41.000-100.000$ & 213 & 18,5 \\
\hline $101.000-250.000$ & 81 & 7,0 \\
\hline nad 251.000 & 68 & 5,9 \\
\hline \multicolumn{3}{|c|}{ trenutna velikost gospodinjstva (število oseb) } \\
\hline $1-2$ & 299 & 26,0 \\
\hline $3-4$ & 353 & 30,7 \\
\hline $5-6$ & 242 & 21,0 \\
\hline $7-8$ & 96 & 8,3 \\
\hline več kot 8 & 161 & 14,0 \\
\hline
\end{tabular}

Opomba: * 1 USD = 199,2 NGN po podatkih iz julija 2015

zakonski stan, število žena, izobrazba, velikost gospodinjstva in vrsta lastništva), njihovi stanovanjski preteklosti (na primer prejšnje bivališče, čas bivanja $\mathrm{v}$ trenutnem bivališču in Ayobu, razlogi za prebivanje v Ayobu), značilnostih trenutnega stanovanja ali hiše (vrsta hiše, stranišče, vodni vir, način odstranje- vanja odpadkov, število spalnic, število gospodinjstev, ki živijo $\mathrm{v}$ isti stavbi ter si delijo kuhinjo in kopalnico, igralne površine za otroke) in stanovanjskih aspiracijah (potreba po dodatnih spalnicah, prehod $\mathrm{k}$ lastniškemu stanovanju ali hiši, čas predlagane selitve, predlagana lokacija, razlogi za predlagano selitev, predlagana vrsta hiše). Poleg tega smo zbirali podatke o značilnostih soseske, pri čemer so morali anketiranci na Likertovi lestvici od 1 do 5 oceniti ustreznost javnih storitev in objektov, kot so šole, trgovine, zdravstvene storitve, rekreacija, dovozne ceste, ravnanje $\mathrm{z}$ odpadki in ulična razsvetljava $(1=\gg$ močno se ne strinjam $\ll, 5=»$ močno se strinjam $\ll)$. Stanovalci so morali na enaki lestvici oceniti tudi stopnjo kriminala in skupnostne vezi v Ayobu. Vprašalnik smo predhodno testirali med izbranimi stanovalci na preučevanem območju, na podlagi dobljenih odgovorov pa smo nato pred dejansko izvedbo terenske ankete nekatera vprašanja ustrezno spremenili. Ankete so izvajali prvi avtor in usposobljeni raziskovalni pomočniki, ki so večkrat obiskali sosesko. Skupaj je bilo razdeljenih 1.200 vprašalnikov, od teh jih je bilo izpolnjenih 1.151. To pomeni, da je bila stopnja odzivnosti 96-odstotna.

Podatke smo analizirali s statističnim programskim paketom SPSS 17.0. Najprej smo izvedli opisno statistično analizo, pri kateri smo izračunali število in odstotek značilnosti anketirancev in njihovih odgovorov na nekatera postavljena vprašanja. Nato smo izvedli kategorično regresijsko analizo, pri kateri smo uporabili tehniko optimalnega skaliranja ali CATREG v SPSS. Postopek CATREG smo izbrali zaradi njegovih prednosti pri analizi nominalnih, ordinalnih in numeričnih podatkov $\mathrm{v}$ primerjavi $s$ splošnimi linearnimi modeli, ker je primerna za obdelavo manjših vzorcev in vključuje najmanj domnev (Shrestha, 2009). S postopkom CATREG smo preučili pojasnjeno varianco $R^{2}$ in določili prediktorje stanovanjskih aspiracij med anketiranci. Odvisna spremenljivka je bila namera anketirancev, da se preselijo. Podatke o tem smo zbrali tako, da smo anketirancem zastavili to vprašanje: »Ali se v prihodnosti nameravate preseliti v drugo hišo? « Anketiranci so lahko odgovorili z da (2) ali ne (1). Odvisno spremenljivko smo pretvorili $\mathrm{v}$ nepravo spremenljivko z vrednostjo 0 . Na podlagi pregleda literature smo določili 32 neodvisnih spremenljivk in jih razvrstili v tri skupine: osebne značilnosti anketirancev (11 spremenljivk), stanovanjska preteklost ( 9 spremenljivk) in značilnosti trenutnega bivališča (12 spremenljivk). Preučevali smo te razloge za preselitev: (a) »selitev v lastno hišo «; (b) »slabo stanje trenutnega bivališča, vključno z neprimerno infrastrukturo «; (c) » pričakovane spremembe velikosti gospodinjstva «; (d) »želja po uporabi lastne kuhinje in kopalnice «; (e) »bližina prijateljev in družine « ter $(\mathrm{f}) \gg$ drugi razlogi ; kodirali smo jih z vrednostmi od 1 do 6. Pri izvajanju postopka CATREG smo za spremenljivko » razlogi za predlagano selitev « uporabili povprečno vrednost odgovorov anketirancev, ki so izrazili željo po selitvi in navedli razlog. Vse kategorične spre- 
Preglednica 2: Ocena javnih objektov in storitev v soseski, ki so jo podali anketiranci.

\begin{tabular}{|c|c|c|}
\hline trditev & $n$ & odstotek (\%) \\
\hline \multicolumn{3}{|c|}{ »V soseski je dovolj dobrih šol.» } \\
\hline Močno se ne strinjam. & 97 & 8,4 \\
\hline Se ne strinjam. & 545 & 47,3 \\
\hline Ne vem. & 34 & 3,0 \\
\hline Se strinjam. & 107 & 9,3 \\
\hline Močno se strinjam. & 230 & 20,0 \\
\hline brez odgovora & 138 & 12,0 \\
\hline \multicolumn{3}{|c|}{ »V soseski je dovolj trgovin.» } \\
\hline Močno se strinjam. & 99 & 8,6 \\
\hline Se ne strinjam. & 576 & 50,0 \\
\hline Ne vem. & 50 & 4,3 \\
\hline Se strinjam. & 193 & 16,8 \\
\hline Močno se strinjam. & 117 & 10,2 \\
\hline brez odgovora & 116 & 10,1 \\
\hline \multicolumn{3}{|c|}{ »Javni prevoz je zadovoljiv.» } \\
\hline Močno se strinjam. & 65 & 5,6 \\
\hline Se ne strinjam. & 286 & 24,8 \\
\hline Ne vem. & 108 & 9,8 \\
\hline Se strinjam. & 171 & 14,8 \\
\hline Močno se strinjam. & 402 & 34,9 \\
\hline brez odgovora & 119 & 10,1 \\
\hline \multicolumn{3}{|c|}{ "Stopnja kriminala je visoka.» } \\
\hline Močno se strinjam. & 67 & 5,8 \\
\hline Se ne strinjam. & 587 & 51,0 \\
\hline Ne vem. & 170 & 14,8 \\
\hline Se strinjam. & 147 & 12,8 \\
\hline Močno se strinjam. & 60 & 5,2 \\
\hline brez odgovora & 120 & 10,4 \\
\hline \multicolumn{3}{|c|}{ "Odpadki se odvažajo redno." } \\
\hline Močno se strinjam. & 53 & 4,6 \\
\hline Se ne strinjam. & 360 & 31,3 \\
\hline Ne vem. & 150 & 13,0 \\
\hline Se strinjam. & 373 & 32,4 \\
\hline Močno se strinjam. & 92 & 8,0 \\
\hline brez odgovora & 123 & 10,7 \\
\hline \multicolumn{3}{|c|}{ "Zdravstvene storitve so zadovoljive.» } \\
\hline Močno se strinjam. & 114 & 9,9 \\
\hline Se ne strinjam. & 455 & 39,5 \\
\hline Ne vem. & 144 & 12,5 \\
\hline Se strinjam. & 84 & 7,3 \\
\hline Močno se strinjam. & 225 & 19,6 \\
\hline brez odgovora & 129 & 11,2 \\
\hline \multicolumn{3}{|c|}{ »V soseski je dovolj objektov za rekreacijo.» } \\
\hline Močno se strinjam. & 240 & 20,9 \\
\hline Se ne strinjam. & 635 & 55,2 \\
\hline Ne vem. & 73 & 6,3 \\
\hline Se strinjam. & 42 & 3,6 \\
\hline
\end{tabular}

\begin{tabular}{lll}
\hline trditev & $n$ & odstotek (\%) \\
\hline Močno se strinjam. & 26 & 2,3 \\
\hline brez odgovora & 135 & 11,7 \\
\hline "Ceste so dobre.» & & \\
\hline Močno se strinjam. & 589 & 51,2 \\
\hline Se ne strinjam. & 381 & 33,1 \\
\hline Ne vem. & 40 & 3,5 \\
\hline Se strinjam. & 13 & 1,1 \\
\hline Močno se strinjam. & 8 & 0,7 \\
\hline brez odgovora & 120 & 10,4 \\
\hline "V soseski je dovolj delujočih uličnih svetilk." & \\
\hline Močno se strinjam. & 539 & 46,8 \\
\hline Se ne strinjam. & 439 & 38,1 \\
\hline Ne vem. & 32 & 2,8 \\
\hline Se strinjam. & 16 & 1,4 \\
\hline Močno se strinjam. & 7 & 0,6 \\
\hline brez odgovora & 118 & 10,3 \\
\hline "Občutek pripadnosti skupnosti je močan.» \\
\hline Močno se strinjam. & 148 & 12,9 \\
\hline Se ne strinjam. & 109 & 9,5 \\
\hline Ne vem. & 210 & 18,2 \\
\hline Se strinjam. & 253 & 22,0 \\
\hline Močno se strinjam. & 304 & 26,4 \\
\hline brez odgovora & 127 & 11,0 \\
\hline
\end{tabular}

menljivke, uporabljene $\mathrm{v}$ več kot dveh kategorijah, smo prav tako pretvorili v neprave spremenljivke. Rezultati so predstavljeni v nadaljevanju.

\section{Izsledki raziskave \\ 4.1 Osebne značilnosti anketirancev}

Družbenoekonomske značilnosti anketirancev, predstavljene v preglednici 1, kažejo, da je bilo največ anketirancev samozaposlenih moških $\mathrm{s}$ srednješolsko izobrazbo, starih od 25 do 60 let. Mesečni dohodek glav gospodinjstev je znašal manj kot 41.000,00 $\mathrm{NGN}^{[1]}$, večina gospodinjstev pa je vključevala vsaj tri osebe. Raziskava je pokazala, da je bila približno četrtina anketiranih moških poligamna. Značilna oblika družine je bila velika razširjena družina, ki je vključevala zakonce, otroke, priženjeno sorodstvo, brate, sestre, vnuke, druge sorodnike, prijatelje in služinčad. Približno $38 \%$ anketirancev je živelo samih ali samo s člani svoje jedrne družine.

\subsection{Značilnosti stanovanj}

Značilnosti stanovanj in hiš smo preučili na ravni sosesk in posameznih bivališč. Rezultati analize na ravni sosesk, predstavljeni v preglednici 2, kažejo, da dostop do javnih storitev in 


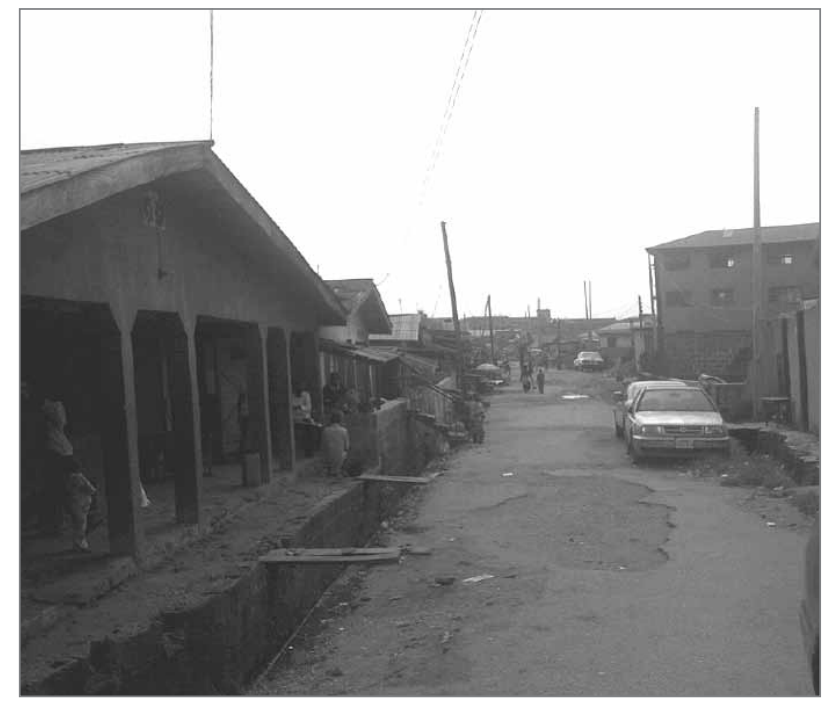

Slika 2: Značilna ulica v Ayobu (prirejeno po Opoku, 2013)

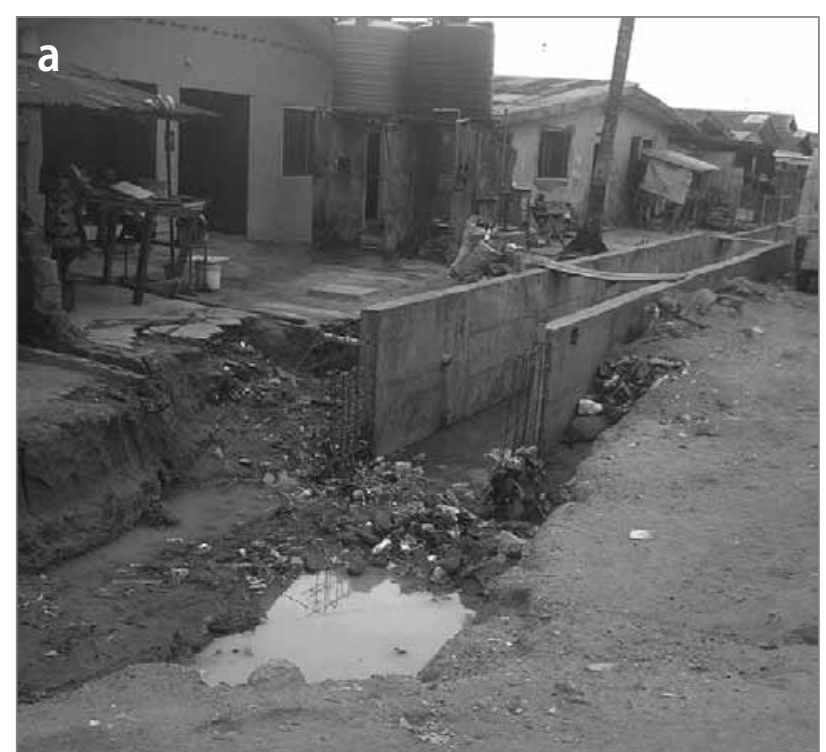

Slika 4: Kanalizacija za meteorno vodo v Ayobu (prirejeno po Opoku, 2013)

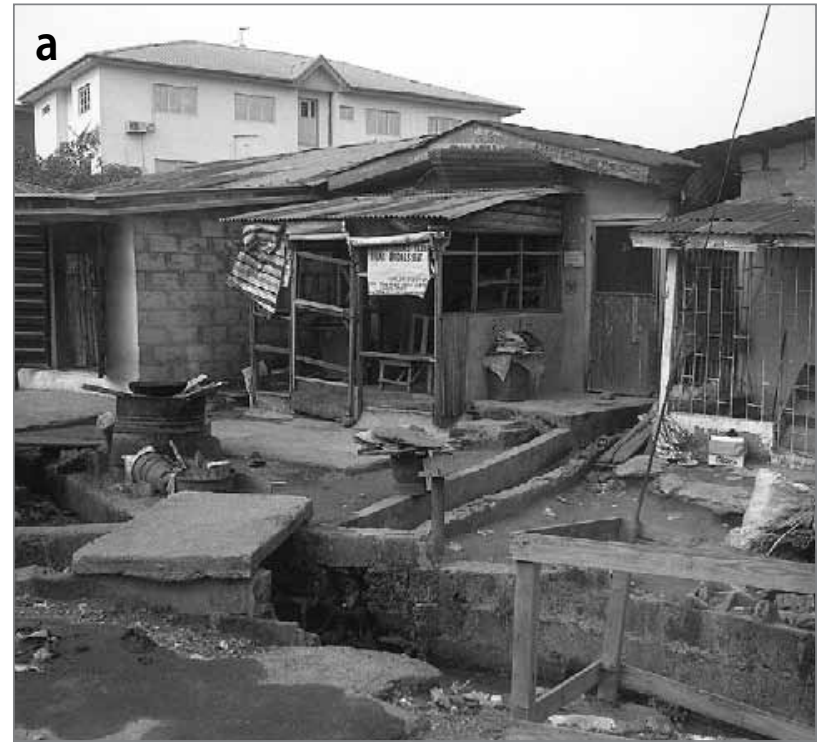

Slika 5: Vrsta stanovanj v Ayobu (prirejeno po Opoko, 2013)
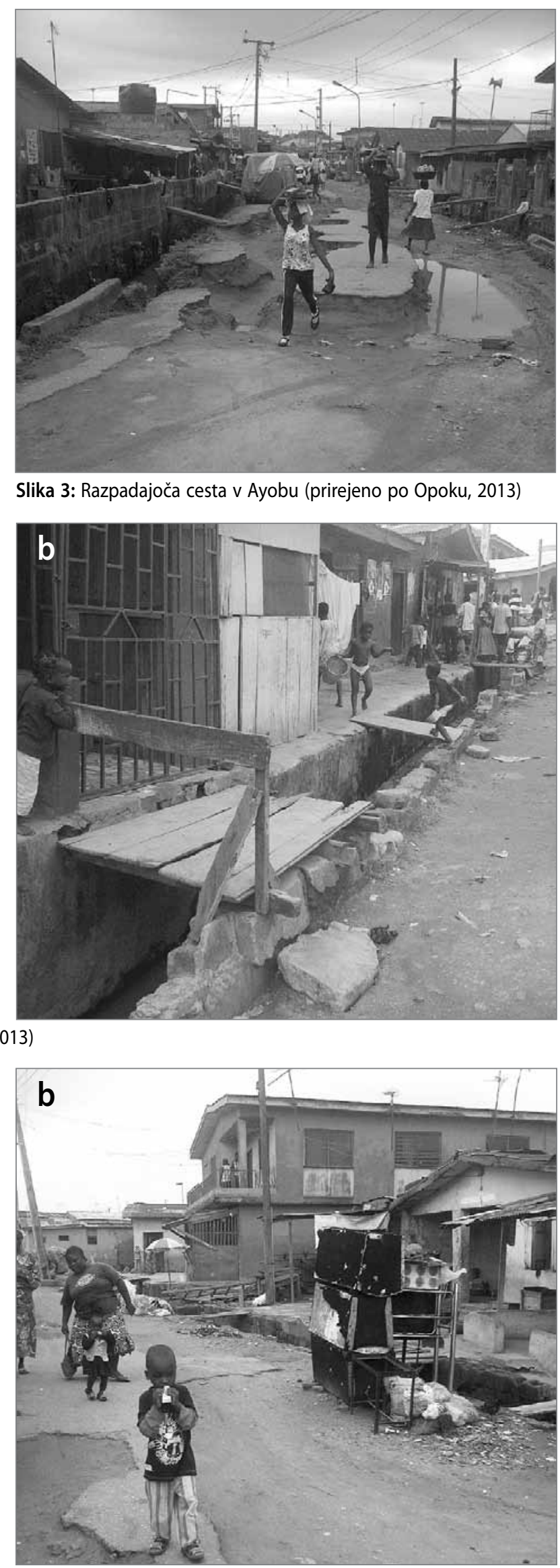

Slika 3: Razpadajoča cesta v Ayobu (prirejeno po Opoku, 2013)

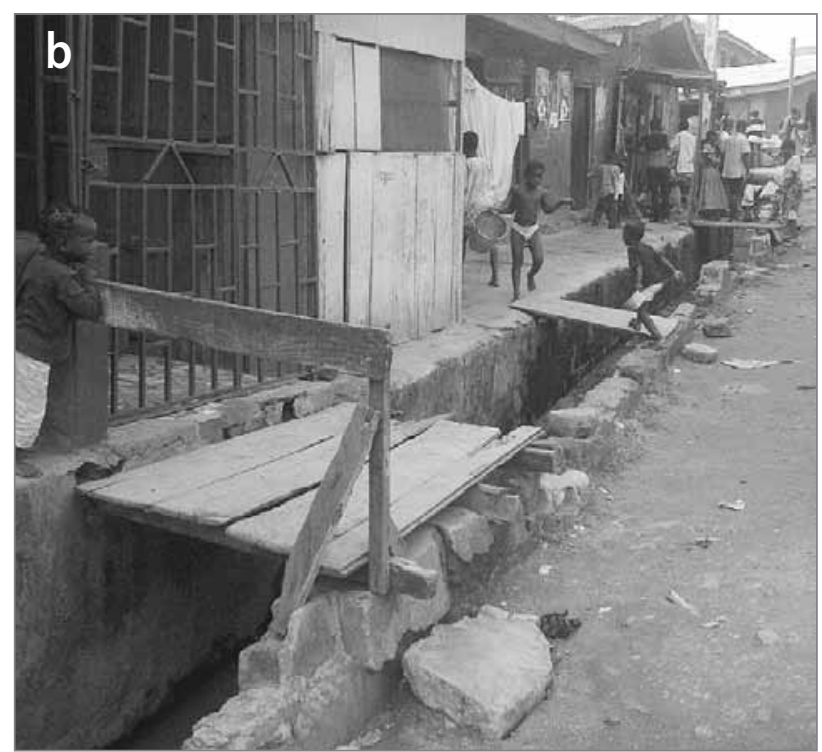


objektov, kot so zdravstvene ustanove, trgovine, izobraževalne ustanove, prostori za rekreacijo in verski objekti, ni ustrezen; večino teh storitev zagotavljajo $\mathrm{v}$ dobiček usmerjeni zasebni podjetniki. Med terensko raziskavo smo ugotovili, da so bile tudi ceste in kanalizacija za meteorno vodo $\mathrm{v}$ razpadajočem stanju (sliki 2 in 3).

Izsledki na ravni posameznih bivališč (preglednica 3) kažejo, da je večina anketirancev (63\%) živela v najemniškem stanovanju, $30 \%$ teh pa v lastni hiši ali stanovanju. $40 \%$ anketirancev je živelo v najetih sobah v skupnih hišah (ang. rooming houses) ${ }^{[2]}, 34,3 \% \mathrm{v}$ stanovanjih in $24,1 \% \mathrm{v}$ enodružinskih hišah. Večina gospodinjstev je živela $\mathrm{v}$ isti stavbi, $\mathrm{v}$ kateri si je kuhinjo in kopalnico delila z drugimi gospodinjstvi. Izkazalo se je, da je bila souporaba kuhinje in kopalnice glavni razlog za konflikte med anketiranci. Poleg tega je $33 \%$ anketirancev imelo samo eno spalnico, $34 \%$ pa dve. Štiri spalnice je imelo $3,9 \%$ anketirancev pet pa $4,0 \%$ teh.

Približno $71 \%$ anketirancev je za odstranjevanje odpadkov uporabljalo storitve zasebnih podjetij v skladu $\mathrm{z}$ vladnimi direktivami, približno tretjina teh pa za to ni uporabljala ustreznih metod. Rezultati (glej preglednico 3) kažejo, da približno $4 \%$ gospodinjstev ni imelo stranišča, $4 \%$ jih je uporabljalo prezračevana, izboljšana stranišča na štrbunk, $26 \%$ je uporabljalo preprosta stranišča na štrbunk, 67 \% gospodinjstev pa je imelo v hiši nameščeno straniščno školjko. Zaradi pomanjkanja stalne tekoče vode ali poškodb pa veliko školjk ni delovalo. Uporabo vedra $v$ funkciji stranišča ni navedel noben anketiranec, kar kaže, da se ta praksa v Ayobu ne uporablja več. Poleg tega je okrog $65 \%$ anketirancev navedlo, da v bližini njihovega doma ni otroških igriš̌č.

\subsection{Stanovanjska preteklost in aspiracije stanovalcev}

Rezultati (glej preglednico 4) kažejo, da se je $11 \%$ anketirancev rodilo v Ayobu, okrog $34 \%$ pa se jih je tja preselilo iz drugih delov Lagosa. Približno $72 \%$ jih v Ayobu živi manj kot deset let, $28,3 \%$ pa vsaj deset let. Veliko teh (28 \%) je prišlo živet $\mathrm{v}$ Ayobo zaradi cenovno ugodnih stanovanjskih možnosti, $23,2 \%$ pa jih tam živi zato, ker imajo v soseski hišo. Večina anketirancev (73\%) se želi nekoč preseliti v novo bivališče. Od teh si $56 \%$ anketirancev želi preseliti v stanovanje $\mathrm{z}$ lastno kuhinjo in kopalnico, $36 \%$ teh pa v enodružinsko hišo; samo $8 \%$ anketirancev si želi najeti sobo v skupni hiši. Zanimivo je, da bi $40 \%$ teh anketirancev ostalo v Ayobu. Med najpogostejšimi razlogi za selitev je $31 \%$ anketirancev navedlo slabo stanje svojih trenutnih bivališč, 23,3\% jih želi imeti
Preglednica 3: Značilnosti bivališč

\begin{tabular}{|c|c|c|}
\hline značilnosti & $n$ & odstotek (\%) \\
\hline \multicolumn{3}{|l|}{ vrsta bivališča } \\
\hline $\begin{array}{l}\text { stanovanje z lastno kuhinjo in ko- } \\
\text { palnico }\end{array}$ & 395 & 34,3 \\
\hline enodružinska hiša & 277 & 24,1 \\
\hline najete sobe v skupnih hišah & 460 & 40,0 \\
\hline drugo & 19 & 1,6 \\
\hline \multicolumn{3}{|l|}{ število spalnic } \\
\hline 1 & 377 & 32,8 \\
\hline 2 & 391 & 34,0 \\
\hline 3 & 162 & 14,1 \\
\hline 4 & 45 & 3,9 \\
\hline 5 & 46 & 4,0 \\
\hline več kot 5 & 130 & 11,3 \\
\hline \multicolumn{3}{|l|}{ vrsta lastništva } \\
\hline najemnik & 720 & 62,6 \\
\hline lastnik stanovanja & 342 & 29,7 \\
\hline družinska hiša & 70 & 6,1 \\
\hline drugo & 19 & 1,7 \\
\hline \multicolumn{3}{|l|}{ vodni vir } \\
\hline vodovod (v hiši) & 188 & 16,3 \\
\hline javne pipe & 198 & 17,2 \\
\hline vodnjak & 350 & 30,4 \\
\hline prodajalci vode & 318 & 27,6 \\
\hline deževnica/potok & 12 & 1,0 \\
\hline drugo & 84 & 7,3 \\
\hline vrtina & 1 & 0,1 \\
\hline \multicolumn{3}{|l|}{ odstranjevanje odpadkov } \\
\hline zasebna podjetja & 817 & 71,0 \\
\hline sežiganje & 274 & 23,8 \\
\hline zakopavanje & 23 & 2,0 \\
\hline polje/reka/prazna parcela & 22 & 1,9 \\
\hline drugo & 15 & 1,3 \\
\hline \multicolumn{3}{|l|}{ vrsta stranišča } \\
\hline brez & 40 & 3,5 \\
\hline straniščna školjka & 770 & 66,9 \\
\hline $\begin{array}{l}\text { prezračevano, izboljšano stranišče } \\
\text { na štrbunk }\end{array}$ & 46 & 4,0 \\
\hline stranišče na štrbunk & 295 & 25,6 \\
\hline \multicolumn{3}{|c|}{ število gospodinjstev, ki si delijo kuhinjo in kopalnico } \\
\hline 1 & 159 & 13,8 \\
\hline 2 & 257 & 22,3 \\
\hline $3-4$ & 166 & 14,4 \\
\hline $5-6$ & 169 & 14,7 \\
\hline $7-9$ & 169 & 14,7 \\
\hline več kot 9 & 231 & 20,1 \\
\hline
\end{tabular}




\begin{tabular}{|c|c|c|}
\hline spremenljivke & $n$ & odstotek (\%) \\
\hline \multicolumn{3}{|l|}{ prejšnje prebivališče } \\
\hline rojeni v Ayobu & 123 & 10,7 \\
\hline drugod v Ayobu & 476 & 41,3 \\
\hline Lagos (zunaj Ayoba) & 390 & 33,9 \\
\hline drugo mesto & 112 & 9,7 \\
\hline podeželje & 50 & 4,3 \\
\hline \multicolumn{3}{|l|}{ čas bivanja v Ayobu (v letih) } \\
\hline manj kot 5 & 432 & 37,5 \\
\hline $5-9$ & 397 & 34,5 \\
\hline $10-19$ & 185 & 16,1 \\
\hline $20-29$ & 83 & 7,2 \\
\hline več kot 29 & 54 & 4,7 \\
\hline \multicolumn{3}{|l|}{ razlog za bivanje v Ayobu } \\
\hline dobra lokacija & 74 & 6,4 \\
\hline bližina prijateljev in družine & 228 & 19,8 \\
\hline bližina javnih objektov in storitev & 145 & 12,6 \\
\hline $\begin{array}{l}\text { cenovno ugodne stanovanjske } \\
\text { možnosti }\end{array}$ & 318 & 27,6 \\
\hline lastnik stanovanja ali hiše & 331 & 28,7 \\
\hline drugo & 55 & 4,8 \\
\hline \multicolumn{3}{|l|}{ lastništvo drugih hiš } \\
\hline ne & 214 & 18,6 \\
\hline $\mathrm{da}$ & 937 & 81,4 \\
\hline \multicolumn{3}{|c|}{ želja po selitvi v drugo hišo v prihodnosti } \\
\hline da & 838 & 72,8 \\
\hline ne & 313 & 27,2 \\
\hline
\end{tabular}

lastniško stanovanje oziroma hišo, 18 \% pa je kot največji razlog navedlo pričakovane spremembe v velikosti gospodinjstva. Drugi razlogi so vključevali željo po uporabi lastne kuhinje in kopalnice (13\%) in bližino družbenih mrež (8\%). Zanimivo je, da je približno $52 \%$ anketirancev menilo, da bi lastniško stanovanje oviralo njihovo mobilnost, približno $45 \%$ jih je navedlo, da so najemniki zato, ker se pogosto selijo, približno $75 \%$ pa jih verjame, da se bo njihov dohodek sčasoma izboljšal in jim omogočil uresničitev sanj glede lastniškega stanovanja.

\subsection{Dejavniki, ki vplivajo na stanovanjske aspiracije}

Da bi določili dejavnike, ki so vplivali na stanovanjske aspiracije anketirancev, smo izvedli postopek CATREG, pri čemer smo za odvisno spremenljivko uporabili »namera o selitvi«, preostalih 32 spremenljivk, predstavljenih v preglednici 5, pa kot neodvisne. Rezultati razkrivajo, da lahko velik delež variance odvisne spremenljivke pojasnimo z regresijskim modelom, pri čemer je multipli $R=0,769$, popravljeni $R^{2}=0,346$ in $R^{2}=0,591$. To pomeni, da regresijski model pojasni pribli-

žno 59 \% variance stanovanjskih aspiracij anketirancev. Poleg tega na podlagi rezultata $F=2,408$ in $p=0,000$ ugotovimo, da so rezultati regresijskega modela statistično pomembni pri $p<0,005$. Sedem od 32 spremenljivk, vključenih v regresijski model, je pomembno napovedalo stanovanjske aspiracije, in sicer so bile to spremenljivke » razlogi za selitev «, » način odstranjevanja odpadkov «, » skupna kuhinja in kopalnica «, »zaposlitveni status «, » starost «, »zakonski stan « in » razlogi za bivanje v Ayobu «. Največjo vrednost betakoeficienta je imela spremenljivka »skupna kuhinja in kopalnica « $(\beta=0,467$; $F=5,239 ; p=0,001)$, kar pomeni, da je najbolje napovedala stanovanjske aspiracije, sledile pa so ji spremenljivke »način odstranjevanja odpadkov $\ll(\beta=0,389 ; F=4,140 ; p=0,003)$, zakonski $\operatorname{stan}(\beta=0,302 ; F=4,196 ; p=0,003)$ in $\gg$ razlogi za predlagano selitev $\ll(\beta=0,211 ; F=3,777 ; p=0,000)$.

\section{Razprava}

Glavni cilj raziskave je bil preučiti značilnosti stanovanj, analizirati stanovanjsko preteklost in aspiracije stanovalcev ter določiti dejavnike, ki vplivajo na stanovanjske aspiracije prebivalcev Ayoba. Razprava o izsledkih se zato osredotoča na tri vidike. Prvič, rezultati analize so pokazali, da je večina anketirancev menila, da nima ustreznega dostopa do zdravstvenih storitev, trgovin, izobraževanja, možnosti rekreacije, dobrih cest, ulične razsvetljave in drugih storitev v soseski. Prav tako so anketiranci slabo ocenili pogostnost odvoza gospodinjskih odpadkov. To je bilo mogoče pričakovati glede na to, da je Ayobo neformalno naselje in da so dosedanje raziskave (Morka, 2007, in Gunter, 2014) pokazale, da je razporeditev osnovnih družbenih storitev in infrastrukture $\mathrm{v}$ neformalnih naseljih $\mathrm{v}$ mestih na globalnem jugu neuravnotežena. Večina anketirancev je živela $\mathrm{v}$ najemniških sobah $\mathrm{v}$ skupnih hišah, pri čemer so vodo $\mathrm{v}$ glavnem pridobivali iz vodnjakov ali pri prodajalcih vode. To običajno povzroča prenapolnjenost in pomanjkanje zasebnosti, razmere pa dodatno slabšata tudi veliko število večstanovanjskih stavb ter visoka stopnja skupne rabe kuhinje in kopalnice. Ti izsledki o značilnostih stanovanj v Ayobu dajejo vpogled v značilnosti stanovanj $\mathrm{v}$ neformalnih naseljih $\mathrm{v}$ hitro rastočih mestih veliko držav v razvoju.

Drugič, izsledki o tem, da gre pri večini anketirancev za samozaposlene ljudi z nizkimi dohodki, ki živijo v najetih stanovanjih, se ujemajo z družbenoekonomskih profilom zvezne države Lagos in drugih urbanih središč v Nigeriji (UN-HABITAT, 2006). Veliko anketirancev je navedlo, da bi se radi odselili iz svojega trenutnega bivališča, kar kaže na njihovo nezadovoljstvo s trenutnimi bivališči. Anketa je pokazala, da so bili glavni razlogi za predlagano mobilnost slabo stanje trenutnega bivališča, vključno z neustrezno infrastrukturo, prehod $\mathrm{k}$ lastniškemu stanovanju, pričakovane spremembe velikosti 
Preglednica 5: Dejavniki, ki vplivajo na stanovanjske aspiracije

\begin{tabular}{|c|c|c|c|c|c|}
\hline \multirow[t]{2}{*}{ spremenljivke } & \multicolumn{5}{|c|}{ standardizirani koeficienti } \\
\hline & beta $(\beta)$ & SE & $d f$ & $F$ & Sig \\
\hline čas predlagane selitve & 0,090 & 0,175 & 1 & 0,264 & 0,608 \\
\hline predlagana selitev & 0,182 & 0,144 & 4 & 1,589 & 0,180 \\
\hline razlogi za predlagano selitev & 0,211 & 0,109 & 8 & 3,777 & $0,000^{*}$ \\
\hline predlagana vrsta hiše & 0,319 & 0,196 & 3 & 2,652 & 0,051 \\
\hline vodni vir & 0,226 & 0,154 & 5 & 2,160 & 0,061 \\
\hline način odstranjevanja odpadkov & 0,389 & 0,191 & 4 & 4,140 & $0,003^{*}$ \\
\hline vrsta stranišča & 0,147 & 0,112 & 3 & 1,723 & 0,164 \\
\hline skupna kuhinja in kopalnica & 0,467 & 0,204 & 4 & 5,239 & $0,001^{*}$ \\
\hline število gospodinjstev, ki si z anketirancem delijo kuhinjo in kopalnico & 0,339 & 0,237 & 3 & 2,039 & 0,111 \\
\hline pogostnost konfliktov & 0,057 & 0,235 & 2 & 0,059 & 0,943 \\
\hline verjeten čas prehoda k lastniškemu stanovanju ali hiši & $-0,029$ & 0,266 & 1 & 0,012 & 0,913 \\
\hline zaposlitveni status & 0,184 & 0,107 & 4 & 2,980 & $0,021^{*}$ \\
\hline spol & 0,046 & 0,052 & 1 & 0,797 & 0,373 \\
\hline starost & 0,259 & 0,119 & 2 & 4,753 & $0,010^{*}$ \\
\hline zakonski stan & 0,302 & 0,148 & 4 & 4,196 & $0,003^{*}$ \\
\hline število žena & $-0,087$ & 0,151 & 2 & 0,333 & 0,717 \\
\hline stopnja izobrazbe & $-0,085$ & 0,224 & 2 & 0,143 & 0,867 \\
\hline mesečni dohodek & 0,090 & 0,180 & 3 & 0,249 & 0,862 \\
\hline velikost gospodinjstva & 0,110 & 0,269 & 2 & 0,167 & 0,846 \\
\hline število otrok, mlajših od 18 let & $-0,250$ & 0,278 & 3 & 0,806 & 0,492 \\
\hline sorodstveni odnos z drugimi člani gospodinjstva & 0,045 & 0,063 & 4 & 0,501 & 0,735 \\
\hline prejšnje bivališče & 0,077 & 0,081 & 4 & 0,894 & 0,469 \\
\hline čas bivanja v Ayobu & 0,268 & 0,184 & 1 & 2,129 & 0,147 \\
\hline vrsta trenutne hiše & 0,137 & 0,124 & 3 & 1,232 & 0,300 \\
\hline razlogi za bivanje v Ayobu & 0,145 & 0,091 & 6 & 2,525 & $0,023^{*}$ \\
\hline čas bivanja $v$ trenutni hiši & $-0,106$ & 0,143 & 2 & 0,546 & 0,581 \\
\hline število spalnic & 0,191 & 0,165 & 3 & 1,342 & 0,263 \\
\hline druge osebe v gospodinjstvu, ki služijo denar & $-0,221$ & 0,176 & 3 & 1,571 & 0,199 \\
\hline število gospodinjstev, ki si z anketirancem delijo stavbo & $-0,115$ & 0,158 & 4 & 0,536 & 0,709 \\
\hline potreba po dodatnih spalnicah & 0,070 & 0,090 & 1 & 0,595 & 0,441 \\
\hline trenutna oblika lastništva & 0,208 & 0,152 & 2 & 1,873 & 0,157 \\
\hline zagotovljeni prostori za otroško igro & 0,098 & 0,134 & 1 & 0,541 & 0,463 \\
\hline
\end{tabular}

Opomba: *statistično pomembno na ravni 0,05

gospodinjstva, želja po uporabi lastne kuhinje in kopalnice in večja bližina družbenih mrež. To so nedvomno dobri razlogi za stanovanjsko mobilnost, na kar sta v prejšnjih raziskavah opozorila tudi Edwards (2005) in Uršič (2005). Poleg tega je raziskava pokazala, da se dve tretjini anketirancev, ki se želijo preseliti, nameravata preseliti $\mathrm{v}$ stanovanja $\mathrm{z}$ lastno kuhinjo in kopalnico. Anketiranci bi se raje preselili v stanovanja, da bi imeli več zasebnosti in več možnosti za ustvarjanje dohodka. To se ujema z izsledki raziskave podjetja Outside Consultants (2009), ki je pokazala, da se predvsem mladi želijo preseliti v stanovanja, hkrati pa se ne ujema z ugotovitvami, razvidnimi iz pregleda literature, po katerih naj bi se v drugih državah predvsem starejši ljudje želeli preseliti v samostojne hiše (Curtin University, 2013). Te razlike so lahko posledica različnih družbenoekonomskih in kulturnih okoliščin, v katerih so bile opravljene raziskave. Dosedanje raziskave so se osredotočale na razvite zahodnjaške države, $v$ katerih so stanovanjski trgi dobro razviti, gospodinjstva pa imajo večji dostop do hipotek, s katerimi si lahko kupijo že zgrajene hiše. V Nigeriji pa večina gospodinjstev zgradi hišo s svojimi prihranki, zato bi bilo lastništvo celotnega stanovanjskega bloka dobra naložbena poteza, saj bi lahko lastniki živeli v enem stanovanju in druga oddajali v najem. Naši podatki pa kažejo, da bi anketiranci najraje živeli v stanovanjih $\mathrm{z}$ lastno kuhinjo in kopalnico, kjer jim teh ne bi bilo treba deliti z drugimi, kot je to običajno $v$ skupnih hišah. 
Izsledki, predstavljeni v prejšnjem odstavku, se ujemajo z ugotovitvami iz literature (Lall idr., 2005), ki kažejo, da prebivalci neformalnih naselij svoje soseske dojemajo kot začasna bivališča, iz katerih se želijo preseliti v boljša. Čeprav nekatere raziskave (Ibem in Aduwo, 2013, in Jasen, 2012) kažejo, da imajo gospodinjstva, ki s svojim bivališcem niso zadovoljna, tri možnosti (da preprosto prenašajo trenutne razmere, da bivališča preuredijo ali da se preselijo), naši podatki razkrivajo, da se večina anketirancev želi preseliti. To se ujema z ugotovitvijo, da je večina anketirancev najemnikov, ti pa stanovanj ne morejo preurediti na svojo pest in tako uresničiti svojih stanovanjskih aspiracij. Po drugi strani številni, ki se nameravajo preseliti, preprosto prenašajo trenutne razmere, dokler se njihovi dohodki ne izboljšajo in jim omogočijo uresničitev stanovanjskih aspiracij (to je navedlo $75 \%$ tistih, ki se želijo odseliti iz trenutnega bivališča).

Nekateri anketiranci želijo ostati na preučevanem območju. To pomeni, da se kljub nezadostnemu dostopu do javnih storitev in objektov ter slabim stanovanjskim pogojem v Ayobu dobro počutijo. Gre predvsem za starejše, gospodinjstva z lastno hišo in ljudi, ki so se v Ayobu rodili. Drugi razlogi za to, da se ne želijo odseliti, so lahko tudi razmeroma nizka stopnja kriminala, čas bivanja na tem območju ter to, da želijo živeti blizu prijateljev in drugih družinskih članov (glej preglednici 2 in 4). Ti izsledki se ujemajo $s$ prejšnjimi raziskavami (Steele, 2010; Croucher, 2008, in Oldfield, 2014), ki so pokazale, da se ljudje običajno nočejo preseliti na novo lokacijo zaradi dejavnikov, kot so vzpostavljene družbene mreže, pridobljena identiteta in navezanost na kraj. Dejstvo, da večina anketirancev $(63 \%) \mathrm{v}$ Ayobu živi že več kot pet let in da jih je bilo 85,9\% v Ayobu rojenih ali pa so pred priselitvijo v Ayobo živeli v Lagosu (preglednica 4), se ujema z ugotovitvijo Philippa Guillauma in Myriam Houssay-Holzschuch (2002), da ni nujno, da so prebivalci revnejših naselij novinci v urbanem okolju.

V zvezi s prediktorji stanovanjskih aspiracij v Ayobu je anketa pokazala, da je stanovanjske aspiracije anketirancev pomembno napovedalo sedem dejavnikov, od katerih se trije (zakonski stan, starost in zaposlitveni status) nanašajo na družbenoekonomske značilnosti prebivalcev. To se ujema s prejšnjimi raziskavami (Hall, 2008, in Outside Consultants, 2009), ki so pokazale, da pri stanovanjskih aspiracijah igrajo pomembno vlogo družbenoekonomske značilnosti, kot so starost, zaposlitev in zakonski stan. Eden od ugotovljenih prediktorjev se nanaša na razloge za predlagano preselitev. Naši podatki razkrivajo, da so razlogi povezani: (a) s slabim stanjem trenutnega bivališča, (b) s potrebo po spremembi lastniškega statusa iz najemnika v lastnika, (c) s pričakovanimi spremembami velikosti gospodinjstva, (d) z željo po uporabi lastne kuhinje in kopalnice ter e) z željo po bivanju blizu prijateljev in družine. Ti razlogi so podobni dejavnikom, za katere je bilo v prejšnjih raziskavah (Croucher, 2008, in Steele, 2010) ugotovljeno, da vplivajo na stanovanjske aspiracije. Preostali trije dejavniki (način odstranjevanja odpadkov, skupna raba kuhinje in kopalnice ter razlogi za bivanje v Ayobu) so povezani z značilnostmi stanovanj in sosesk v Ayobu. Natančneje, rezultati so pokazali, da se večina gospodinjstev pri odstranjevanju gospodinjskih odpadov zanaša na storitve zasebnih podjetij. Kljub temu anketiranci s temi storitvami niso zadovoljni, saj se odpadki ne pobirajo in odvažajo redno. $V$ zvezi s skupno uporabo kuhinje in kopalnice so rezultati pokazali, da večina anketirancev živi v najetih sobah v skupnih hišah, kjer si morajo gospodinjstva deliti kuhinjo in kopalnico, pri čemer pogosto prihaja do konfliktov. Zato je bila uporaba lastne kuhinje in kopalnice eden od razlogov za to, da se anketiranci želijo odseliti iz trenutnega stanovanja. Razlogi za bivanje v Ayobu temeljijo na številnih dejavnikih, vključno $\mathrm{z}$ dobro lokacijo, bližino prijateljev in družine, cenovno dostopnostjo stanovanj, bližino javnih objektov in storitev in lastništvom. To se nekateri razlogi, za katere sta ABS (1998) in Edwards (2005) ugotovila, da pomembno vplivajo na stanovanjske aspiracije. To lahko pojasni, zakaj so se razlogi za bivanje v Ayobu v anketi izkazali za pomemben prediktor stanovanjskih aspiracij.

\section{Sklep}

V članku so avtorji preučili in analizirali stanovanjske aspiracije prebivalcev neformalnega naselja Ayobo v predmestju Lagosa v Nigeriji. Na podlagi izsledkov raziskave lahko oblikujemo več sklepov. Prvič, pri večini stanovanj v Ayobu gre za najete sobe v skupnih hišah; glave tovrstnih gospodinjstev so večinoma nizko izobraženi samozaposleni posamezniki, gospodinjstva pa si morajo kopalnico in kuhinjo deliti z drugimi. Soseska ima slab dostop do osnovnih družbenih storitev. Drugič, čeprav so najete sobe v skupnih hišah najpogostejša vrsta stanovanj v Ayobu, saj si jih prebivalci z nizkimi dohodki lažje privoščijo, bi večina anketirancev raje živela drugje. Želijo bivati v stanovanjih z lastno kuhinjo in kopalnico in enodružinskih hišah, kjer jim teh ne bi bilo treba deliti. Tretjič, rezultati ankete se ujemajo z obstoječimi raziskavami, ki so pokazale, da lahko družbenoekonomske in demografske značilnosti prebivalcev, stanovanjski pogoji, značilnosti soseske in drugi oprijemljivi dejavniki dobro napovedo stanovanjske aspiracije prebivalcev neformalnih urbanih naselij.

Izsledki te raziskave bi se lahko upoštevali pri politiki in praksi na obravnavanem področju. Prvič, pri reševanju problema pomanjkljive infrastrukture $\mathrm{v}$ neformalnih urbanih naseljih bi se moralo oblikovati tesno partnerstvo med prebivalci teh naselij in vlado. Dejstvo, da se nekateri prebivalci ne želijo odseliti s preučevanega območja, potrjuje, da je na teh območjih velika stopnja družbenega kapitala in občutka pripadnosti skupnosti, 
kar bi lahko pomagalo oblikovati partnerstva med vlado in skupnostjo pri prizadevanjih za izboljšanje dostopa do osnovne infrastrukture na teh območjih. To bi lahko dosegli s pobudami skupnosti za izboljšave in $s$ programi, $\mathrm{v}$ katerih bi dejavno sodelovali prebivalci sosesk.

Drugič, za zadovoljevanje trenutnih stanovanjskih potreb, pričakovanj in aspiracij prebivalcev obravnavanega območja bi morali nepremičninski investitorji namesto $\mathrm{v}$ gradnjo skupnih hiš več vlagati v gradnjo cenovno dostopnih enodružinskih hiš in stanovanjskih blokov. Pri oblikovanju stanovanjske politike in stanovanjskih programov za reševanje stanovanjskih potreb prebivalcev neformalnih urbanih naselij v državah v razvoju je zato poleg fizičnih, tehničnih in gospodarskih dejavnikov nujno treba upoštevati tudi družbeno-kulturne vidike stanovanjskih potreb, vključno $\mathrm{z}$ zasebnostjo.

Tretjič, kljub razlikam v družbenoekonomskem statusu, demografskih značilnostih in kulturnemu ozadju gospodinjstev so dejavniki, ki vplivajo na stanovanjske aspiracije, $v$ razvitih državah podobni tistim, ki smo jih obravnavali v tej raziskavi. To preprosto pomeni, da imajo različne kulture in družbe podobne stanovanjske aspiracije. Zato lahko dejavniki, kot so zakonski stan, starost, zaposlenost, oblika lastništva, trenutne stanovanjske razmere, dostop do osnovne infrastrukture in storitev, družbene mreže in cenovna dostopnost stanovanj, povzročijo pomembne spremembe $\mathrm{v}$ stanovanjskih aspiracijah posameznikov in gospodinjstev v Nigeriji in drugod po svetu.

Ta raziskava ima več omejitev. Predstavljena anketa je bila izvedena samo v enem od mnogih neformalnih naselij, kar pomeni, da izsledkov ne moremo posplošiti na vsa druga neformalna naselja v Lagosu. Druga omejitev raziskave je ta, da v njej nismo primerjali stanovanjskih aspiracij različnih dohodkovnih skupin na obravnavanem območju. Zadnja omejitev pa se nanaša na dejstvo, da smo preučili samo dve tretjini spremenljivk, kar pomeni, da nekatere spremenljivke, povezane s stanovanjskimi aspiracijami, niso bile vključene v raziskavo. Kljub opisanim omejitvam pa raziskava ponuja nov vpogled $\mathrm{v}$ stanovanjske aspiracije prebivalcev neformalnega naselja $\mathrm{v}$ enem najhitreje rastočem velemestu na svetu, $s$ čimer prispeva $k$ trenutno pomembnemu diskurzu o stanovanjih $\mathrm{v}$ neformalnih urbanih naseljih v državah v razvoju.

\section{Akunnaya P. Opoko}

Covenant University, College of Science and Technology, Depart-

ment of Architecture, Ota, Nigerija

E-pošta: akunnaya.opoko@covenantuniversity.edu.ng

\section{Eziyi O. Ibem}

Covenant University, College of Science and Technology, Depart-

ment of Architecture, Ota, Nigerija

E-pošta: ibem.eziyi@covenantuniversity.edu.ng
Ekundayo A. Adeyemi

Covenant University, College of Science and Technology, Depart-

ment of Architecture, Ota, Nigerija

E-pošta: ekundayo.adeyemi@covenantuniversity.edu.ng

\section{Opombe}

[1] 1 USD = 199,2 NGN po podatkih iz julija 2015.

${ }^{[2]}$ Hiše (običajno slabe kakovosti), v katerih se v najem oddajajo sobe, pri čemer običajno v majhni sobi živi cela družina (do šest ljudi). Sobe so razporejene $v$ dve vrsti, vmes je hodnik (sobe gledajo druga proti drugi), kuhinja in kopalnice so skupne in pogosto zunaj, ne $v$ sami hiši (op. prev.).

\section{Viri in literatura}

Aigbavboa, C., in Thwala, W. (2014): Structural equation modelling of building quality constructs as a predictor of satisfaction in subsidised low-income housing. Urbani izziv, 25(supplement), str. S134-S147. DOI: 10.5379/urbani-izziv-en-2014-25-supplement-010

Arthurson, K., Worland, P., in Cameron, H. (2007): A place to call my own: Identifying best practice in housing and mental health. Prispevek je bil predstavljen na konferenci z naslovom State of Australian Cities National Conference, ki je od 28. do 30. novembra potekala v Adelaidu v Avstraliji. Tipkopis.

Asiyanbola, A. R. (2012): Local perspective, aspiration and women empowerment in housing development in Africa: Nigeria. Journal of Humanities and Social Science, 5(4), str. 15-22. DOI: 10.9790/0837-0541522

Australian Bureau of Statistics (1998): Housing motivations and intentions, Western Australia. Raziskovalno poročilo. Canberra.

Australian Bureau of Statistics (2004): Housing motivations and intentions, Western Australia. Raziskovalno poročilo. Canberra.

Baum, S., in Wulff, M. (2003): Housing aspirations of Australian households. Raziskovalno poročilo. Melbourne, Australian Housing and Urban Research Institute.

Baxter, J., in Mcdonald, P. (2004): Trends in home ownership rates in Australia: The relative importance of affordability trends and changes in population composition. Raziskovalno poročilo. Melbourne, Australian Housing and Urban Research Institute.

Clark, W., in Withers Davies, S. (1999): Changing jobs and changing houses: Mobility outcomes of employment transitions. Journal of Regional Science, 39(4), str. 653-673. DOI: 10.1111/0022-4146.00154

Clegg, S., Coulter, A., Edwards, G., in Strachan, V. (2007): Housing aspirations. Edinburg, The Scottish Government.

Community Council of Devon (2011): Housing aspirations of older people living in rural Devon. Exeter, Devon Rural Housing Partnership.

Creswell, J. W. (2009): Research design: Qualitative, quantitative, and mixed methods approaches. Thousand Oaks, Kalifornija, Sage.

Croucher, K. (2008): Housing choices and aspirations of older people. Raziskovalno poročilo. London, University of York Communities and Local Government.

Curtin University (2013): The housing we'd choose: A study for Perth and Peel. Perth, Department of Housing and Planning in Western Australia.

DTZ New Zealand (2005): Housing tenure aspirations and attainment in New Zealand. Raziskovalno poročilo. Aotearoa, Centre for Housing Research New Zealand and Building Research. 
Edwards, L. (2005): Home truths: The reality behind our housing aspirations. London, Shelter.

Fapohunda, T. M. (2012): Women and the informal sector in Nigeria: Implications for development. British Journal of Arts and Social Sciences, 4(1), str. 35-45.

Foley, D. L. (1980): The sociology of housing. Annual Review of Sociology, 6(1), str. 457-478. DOI: 10.1146/annurev.so.06.080180.002325

Gbakeji, J. O., in Magnus, O. O. (2007): Aspects of residential neighbourhood preferences in the Warri metropolis, Delta State Nigeria. Study of Home Community Science. 1(2), str. 121-126.

Giele, J. Z., in Elder, G. H., Jr. (1998): Methods of lifecourse research: Qualitative and quantitative approaches. Thousand Oaks, Kalifornija, Sage.

Grum, B., in Kobal Grum, D. (2015): A model of real estate and psychological factors in decision-making to buy real estate. Urbani izziv, 26(1), str. 82-91. DOI: 10.5379/urbani-izziv-en-2015-26-01-002

Guillaume, P., in Houssay-Holzschuch, M. (2002): Territorial strategies of South African informal dwellers. Urban Forum, 13(2), str. 86-101. DOI: $10.1007 / s 12132-002-0015-0$

Gunter, A. (2014): Renting shacks: Landlords and tenants in the informal housing sector in Johannesburg South Africa. Urbani izziv, 25(supplement), str. S96-S107.

DOI: 10.5379/urbani-izziv-en-2014-25-supplement-007

Hall, L. (2008): Maori and Pacific peoples' housing needs in the Auckland region: A literature review. Raziskovalno poročilo. Auckland, Auckland Regional Council, Nova Zelandija.

Harries, B., Richardson, L., in Soteri-Proctor, A. (2008): Housing aspirations for a new generation: Perspectives from white and South Asian British women. York, Chartered Institute of Housing/Joseph Rowntree Foundation.

Ho, D. C. W., Yau, Y., Law, C. K., Poon, S. W., Yip H. K., in Liusman, E. (2012): Social sustainability in urban renewal: An assessment of community aspirations. Urbani izziv, 23(1), str. 125-139.

DOI: 10.5379/urbani-izziv-en-2012-23-01-005

Hyll, W., in Schneider, L. (2012): The causal effect of watching TV on material aspirations: Evidence from the "valley of the innocent". Referat. Halle (Saale), Halle Institute for Economic Research.

Ibem, E. O. (2011): The contribution of public private partner-

ships (PPPs) to improving accessibility of low-income earner to housing in Southern Nigeria. Journal of Housing and the Built Environment, 26 (2), str. 201-217. DOI: 10.1007/s10901-011-9213-1

Ibem, E. O., in Aduwo, E. B. (2013): Assessment of residential satisfaction in public housing in Ogun State, Nigeria. Habitat International, 40, str. 163-175. DOI: 10.1016/j.habitatint.2013.04.001

Jamiyansuren, B., in Lascu, D. (2012): Consumer aspirations and intentions: An evaluation of housing products and services in Mongolia. Innovative Marketing, 8(4), str. 31-41.

Jansen, S. J. T. (2012): The impact of socio-demographic characteristics, objective housing quality and preference on residential satisfaction. Delovno gradivo. Delft, Delft University of Technology.

Jiboye, A. D. (2009): Evaluating tenants' satisfaction with public housing in Lagos, Nigeria. Town Planning and Architecture, 33(4), str 239-247. DOI: 10.3846/13921630.2009.33.239-247

Kabiru, C. W., Mojola, S. A., Beguy, D., in Okigbo, C. (2013): Growing up at the "margins": Concerns, aspirations, and expectations of young people living in Nairobi. Journal of Research on Adolescence, 23(1), str. 81-94. DOI: 10.1111/j.1532-7795.2012.00797.x
Kolawole, Y. (2015): FG restructures FHA due to under-performance minister. Vanguard Newspaper. Dostopno na: http://www.vanguardngr. com (sneto 2. 3. 2015).

Lacey, L., in Sinai, I. (1996): Do female-headed households have different shelter needs than men? The case of Monrovia, Liberia. Journal of Comparative Family Studies, 27(1), str. 89-108.

Lall, S. V., Suri, A., in Deichmann, U. (2005): Household savings and residential mobility in informal settlements. Poročilo. Washington, Svetovna banka. DOI: 10.1596/1813-9450-3596

Marais, L., Ntema, J., Cloete, J., in Venter, A. (2014): From informality to formality to informality: Extralegal land transfers in an upgraded informal settlement of South Africa. Urbani izziv, 25(supplement), str. S148S161. DOI: 10.5379/urbani-izziv-en-2014-25-supplement-011

Markkanen, S. (2009): Looking to the future: Changing black and minority ethnic housing needs and aspirations. Informativni članek. London, Race Equality Foundation.

Merlo, R., in McDonald, P. (2002): Outcomes of home ownership aspirations and their determinants. Raziskovalno poročilo. Melbourne, Australian Housing and Urban Research Institute.

Morka, F. C. (2007): A place to live: A case study of the ljora-Badia community in Lagos, Nigeria. Poročilo študije primera. Dostopno na: http:// www.habitat.org/grhs/2007 (sneto 27. 4. 2009).

Morrison, P. S. (2005): Changing patterns of home ownership in New Zealand, 1991 to 2001. Report to DTZ, New Zealand. Dostopno na: http:// repository.digitalnz.org (sneto 27. 5. 2015)

Nacionalni statistični urad (2012): Annual abstract of statistics. Abuja.

Oladokun, T. T., in Aluko, B. T. (2012): Public-private partnership in housing delivery in Lagos State, Nigeria. Prispevek je bil predstavljen na konferenci z naslovom International Conference on Construction and Real Estate Management, ki je potekala od 1. do 2. oktobra v Kansas Cityju v Misuriju. Tipkopis.

Oldfield, S. (2014): Intertwining lives and logics: Household and informal economies in Cape Town. Urbani izziv, 25(supplement), str. S36S46. DOI: 10.5379/urbani-izziv-en-2014-25-supplement-003

Opoko, A. P. (2013): Housing tenure in informal settlements: A case study of Ayobo, Lagos State, Nigeria. Doktorska disertacija. Ota, Covenant University, Department of Architecture.

Opoko, A. P., Adeyemi, E. A., in Amole, S. A. (2014): Tenure structure in informal settlements: Implications for housing policy formulation in $\mathrm{Ni}$ geria. Prispevek je bil predstavljen na konferenci z naslovom 7th IRERS IBIMA International Conference, ki je potekala od 29. do 30. aprila v Selangorju v Maleziji. Tipkopis.

Outside Consultants (2009): Appraisal of the housing needs \& aspirations of young people research findings. Gateshead, Gateshead Council.

Pinnegar, S., van den Nouwelant, R., Judd, B., in Randolph, B. (2012): Understanding housing and location choices of retiring Australians in the "baby boom" generation. Raziskovalno poročilo. Sydney, University of New South Wales.

Rahman, T. (2011): Aspirations and compromises: Changes in homestead space relations of the extreme poor after disaster. Terensko poročilo. Daka, Plos Current Disasters.

Rankin, S. (1983): Housing "coloured" aspirations in community of the Durban. Poročilo. Westville Durban, University of Durban, Institute for Social \& Economic Research.

Shapurjee, Y., in Charlton, S. (2013): Transforming South Africa's low-income housing projects through backyard dwellings: Intersections 
with households and the state in Alexandra, Johannesburg. Journal of Housing and the Built Environment, 28(4), str. 653-666. DOI: 10.1007/ s10901-013-9350-9

Shrestha, S. L. (2009): Categorical regression models with optimal scaling for predicting indoor air pollution concentrations inside kitchens in Nepalese households. Nepal Journal of Science and Technology, 10, str. 205-211.

Steele, A. (2010): A qualitative assessment of the housing needs and aspirations of older people in Leicestershire. Raziskovalno poročilo. Leicester, Salford Housing \& Urban Studies Unit University of Salford.

Sunshine Coast University (2011): Housing choice-contemporary demand preferences in the Sunshine Coast. Sippy Downs.

Tsenkova, S. (2014): The housing policy nexus and people's responses to housing challenges in post-communist cities. Urbani izziv, 25(2), str. 90-106. DOI: 10.5379/urbani-izziv-en-2014-25-02-002

UN-HABITAT (2006): National trends in housing - production practices volume 4: Nigeria. Nairobi, United Nations Centre for Human Settlements.

Uršič, M. (2005): Changing the quality of living and housing (residential) mobility in Ljubljana. Urbani izziv, 16(2), str. 156-163.

DOI: 10.5379/urbani-izziv-en-2005-16-02-004 